\title{
Antiplatelet activity of Croton celditifolius
}

\author{
Teresinha de Jesus Carvalho Neiva*,1, Ana Carolina Rabello de Moraes', Carlos Buchele', Moacir \\ Geraldo Pizzolatti', Elbio Antônio D'Amico³, Diana Marli Fries³, Tania Rubia Flores da Rocha ${ }^{3}$
}

\author{
${ }^{1}$ Departamento de Análises Clínicas, Centro de Ciências da Saúde, Universidade Federal de Santa Catarina; ${ }^{2}$ \\ Departamento de Química, Universidade Federal de Santa Catarina, ${ }^{3}$ Laboratório de Hemostasia, Hospital das \\ Clínicas, Faculdade de Medicina, Universidade de São Paulo
}

*Correspondence:

T. J. C. Neiva

Departamento de Análises Clínicas CCS

Universidade Federal de Santa Catarina

Campus Universitário - Trindade 88040-970 - Florianópolis - SC, Brasil E-mail: neiva@ccs.ufsc.br
Croton celtidifolius Baill is a tree found in the Atlantic Forest South of Brazil, mainly in Santa Catarina. The bark and leaf infusions of this medicinal plant have been popularly used for the treatment of inflammatory diseases. The anti-aggregant activity of $\mathrm{C}$. celtidifolius crude extract (CE) and the column chromatography (CC) isolated compounds flavonoids, catechin and gallocatechin were evaluated in human blood platelets. The platelet-rich plasma (PRP) was incubated with different concentrations of flavonóides $(50-200 \mu \mathrm{g} / \mathrm{mL})$ to be tested before platelet aggregation was induced by the agonists adenosine 5'diphosphate (ADP) and collagen. At $200 \mu \mathrm{g} / \mathrm{mL}$ the CE, catechin and gallocatechin markedly inhibited platelet aggregation with the aggregant agents. Using ATP production as an index of platelet secretory capacity, we observed a decreased production of ATP in platelets treated with flavonoids when stimulated by collagen. On the other hand, the flavonoids did not promote inhibitory effect on prothrombin time (PT), thromboplastin time (APTT) and thrombin time (TT). In conclusion, these observations suggest that $\mathrm{C}$. celtidifolius is likely to exert an inhibitory action on platelets in vitro by suppressing secretion and platelet aggregation.

\section{INTRODUCTION}

Activation of platelets plays a key role in haemostasis and circulation. Platelet aggregation is known to be a result of complex signal transduction cascade reactions brought about by stimulants. After activation, platelets provide a catalytic membrane surface for thrombin generation, which accelerates the formation of fibrin, necessary to stabilize thrombin. Key to these events is the presence, on the platelet surface, of receptors that can respond rapidly to soluble agonists, including collagen, thrombin and adenosine 5'diphosphate (Bluestein, 2004; Massberg et al., 2005). Platelet dysfunction contributes in the development and progression of many cardiovascular diseases like arterial hypertension, atherosclerosis and thrombosis. Indeed, it has been reported that patients with hypertension or coronary heart disease tend to have increased platelet reactivity (Hernández Hernández et al., 1997; Maeda, Bydlowski and 
Lopes, 2005). Other studies in hypertensive patients showed that platelets were more sensitive to thrombin (Andrioli et al., 1996; Görlach et al., 2005) and exhibited an elevation in their intracellular free calcium (Erne et al., 1984; Bruschi et al., 1985). This later may potentiate the platelet activity and increase the risk of thrombosis. Therefore, many investigations were carried out in order to prevent this abnormal hyperactivity of platelets reported in cardiovascular disorders by using different therapies, including use of medicinal plants. In fact, it has been shown that some plants, such as garlic (Rahman and Billington, 2000) and tomato (Dutta-Roy, Crosbie and Gordon, 2001), may be beneficial in protecting against cardiovascular diseases as a result of the platelet aggregation inhibition. There are many nutritive and non-nutritive compounds present in the diet that may affect platelet function in various ways. Therefore, the compounds that inhibit platelet function are of great interest. In fruits and vegetables, there are many bioactive compounds, such as polyphenolic, vitamins and carotenoids (Olas et al., 2005; Rechner and Kroner, 2005).

Flavonoids represent an interesting group of polyphenols natural compounds found ubiquitously in the plant-derivated constituents on the human diet and many studies indicates that certain flavonoids have been shown to modify eicosanoids synthesis (antiprostanoid and antiinflammatory responses), protect low-density lipoprotein from oxidation, preventing atherosclerotic plaque formation, and prevent platelet aggregation (Cody, 1988; Coni et al., 2000; Olas et al., 2005).

Croton celtidifolius Baill, commonly known as "Sangue-de-adave" is a tree found in the South Atlantic Forest of Brazil, mainly in Santa Catarina State. The bark and leaf infusions of this medicinal plant have been popularly used for the treatment of ulcer, rheumatism and other inflammatory diseases. Several compounds with pharmacological activity have been previously isolated from other Croton spp. It has been reported that latex of $C$. lechleri contains the alkaloid taspine, which may be the active principle responsible for the anti-inflammatory (Vaisberg et al., 1989) and antitumourogenic activity (Chen, Cai and Phillipson, 1994) of this plant. However, studies about chemical constituents, as well as pharmacological effects of $C$. celtidifolius, are still limited. Recently, Nardi et al. (2003) showed that CE of $C$. celtidifolius and two isolated compounds, catechin and gallocatechin, have significant anti-inflammatory and antioxidant activity. Nevertheless, there is no information about the eventual influence of this medicinal plant on haemostasis. The haemostatic system depends on the interaction between wall of sanguineous vase and platelets circulating factors. The platelets reactions as aggregation, peroxidation and secretion are considered as a primary replay. The proteins that participate in the coagulation process are enclosed in the reply and will play in the haemostatic regulation. Thus, the purpose of the present study was to investigate the effects of $C$. celtidifolius $\mathrm{CE}$ and the isolated compounds, catechin and gallocatechin, in platelet activity and in coagulation.

\section{MATERIALS AND METHODS}

\section{Plant material}

C. celtidifolius Baill was collected in March, 2000, from Orleans city, SC, Brazil. The voucher specimen was identified with the collection documenting number 31272 at the Bottany Department, UFSC, by Prof. Dr. Daniel de Barcelos Falkenberg and deposited in the author's laboratory.

\section{Extraction and isolation}

The extraction and isolation of the catechin and gallocatechin were performed as described previously (Nardi et al., 2003). Air-dried bark (154 g) was chopped into small pieces and extracted three times with $250 \mathrm{~mL}$ of $80 \%$ aqueous EtOH at room temperature. The combined extracts were filtered and the solvent was evaporated in a vacuum to give $42,9 \mathrm{~g}$ of the crude hydroalcoolic extract (EB). The crude hydroalcoolic extract was successively partitioned with ether, ethyl acetate and n-butanol. The ethyl acetate fraction was chromatographed over a column of silica gel water $(20 \%)$ inactivated and eluted with hexane/acetate gradient. The first fractions containing catechin and gallocatechin were further purified by flash chromatography using hexane $40 \% /$ EtOAc $59 \% / \mathrm{AcOH} 1 \%$ as isocratic eluent.

\section{Reagents}

Adenosine diphosphate (ADP), collagen and luciferin/luciferase were purchased from Chronolog Corpration, USA. Thromboplastin (PT test), elagic phospholipide (APTT test) and thrombin reagents were purchased from Organon Technika, Durham, NC, USA.

\section{Subjects}

The study was approved by the Ethics Committee of the University, UFSC, Florianópolis, SC, Brazil, and included 15 healthy volunteers who gave written informed consent to participate, process 150-03/2002.

\section{Isolation of platelets}

Platelet rich plasma (PRP) was prepared by centrifugation of citrated blood at $22^{\circ} \mathrm{C}$ for $6 \mathrm{~min}$. at $400 \mathrm{~g}$. Platelets were adjusted to $3.0 \times 10^{8} \mathrm{cell} / \mathrm{mL}$ with sterile saline. 


\section{Measurement of platelet aggregation (PA)}

PA was determined by the turbidimetric method (Born, Cross, 1963) using a Chronolog Aggregometer. Aliquots of $400 \mu \mathrm{L}$ of a platelet suspension were transferred into a small cuvette and stirred at a constant speed of $180 \mathrm{~g}$ at $37^{\circ} \mathrm{C}$. The platelets were pre-incubated with different fractions of CE, catechin, gallocatechin or vehicle $(1 \mathrm{mM}-\mathrm{NaOH})$ for $5 \mathrm{~min}$ at $37^{\circ} \mathrm{C}$, before the addition of aggregant agents. The extent of aggregation (\%) was recorded continually for $5 \mathrm{~min}$ after addition of the agonists.

\section{Measurement of platelet secretion induced by collagen}

Platelet secretion (\%) was evaluated using the system luciferin/luciferase according Pascual and Romay (1992). The platelets were pre-incubated with different concentrations of compounds or with the vehicle $(1 \mathrm{mM}$ $\mathrm{NaOH}$ ) for $5 \mathrm{~min}$ at $37^{\circ} \mathrm{C}$, before the addition of $4 \mu \mathrm{g} / \mathrm{mL}$ of collagen.

\section{Measurement of blood coagulation}

Human blood was obtained from 15 individual healthy donors without history of bleeding or thrombosis. Nine parts of blood collected by venipuncture were drawn into one part of $3,8 \%$ trisodium citrate. Blood was centrifuged for $10 \mathrm{~min}$ at $900 \mathrm{~g}$, and the plasma stored at $20^{\circ} \mathrm{C}$ until were tested. Activated prothrombin time (PT), activated partial thromboplastin time (APTT) and thrombin time (TT) were evaluated according to Triplett et al. (1978). The plasma was pre-incubated with different concentrations of inhibitors or vehicle $(1 \mathrm{mM}-\mathrm{NaOH})$ for 2 min at $37^{\circ} \mathrm{C}$ and coagulation time was measured using a Net Lab Digital Coagulation System.

\section{Statistical Analysis}

Data were expressed as mean \pm SD. The TukeyKrammer test was employed to determine differences between the groups. Differences were considered significant when the probability was $p<0,05$. The statistical program Instat-2 was utilized.

\section{RESULTS AND DISCUSSION}

Many different herbal components in folk medicine are antiplatelet agents that inhibit platelet activation and have been used in the management of cardiovascular disorders. The objective of the present study was to determine whether C. celtidifolius would affect platelet function and blood coagulation. A control aggregation test induced by collagen or ADP was systematically carried out in the beginning of each experiment in order to verify the good physiological status of platelets. Human blood platelets were incubated in the presence of CE, catechin and gallocatechin for $5 \mathrm{~min}$ at $37^{\circ} \mathrm{C}$. Using $200 \mu \mathrm{g} / \mathrm{mL}$ of CE, or of its isolated compounds, was sufficient to exhibit a significant inhibition by two types of agonists. The effect of CE, catechin and gallocatechin on platelet aggregation induced by collagen is shown in Table I. Treatment with $200 \mu \mathrm{g} / \mathrm{mL}$ of CE, catechin and gallocatechin were sufficient to induce a significant inhibition of $75 \%, 60 \%$ and $65 \%$ respectively. Subsequently, we examined the effect of these flavonoids in the presence of ADP. The results obtained with these compounds were sufficient to exhibit a potent inhibitory effect on platelet aggregation induced by this agonist (Table II). The results obtained from the platelet aggregation study demonstrated that $C$. Celtifoulius promoted changes in platelet metabolism with inhibitory effect of the primary hemostasis. We observed, in PRP, that the shape change and the primary platelet aggregation phase induced by the two agonists was not affected in the presence of these flavonoids, on the other hand, the second platelet aggregation phase was significantly inhibited.

TABLE I - Effects of Croton celtidifolius Baill, crude extract $(\mathrm{CE})$, catechin and gallocatechin on platelet aggregation induced by $4 \mu \mathrm{g} / \mathrm{mL}$ of collagen.

\begin{tabular}{lcc}
\hline Treatment & & Collagen $(\%)$ \\
\hline Control $(1 \mathrm{mM}-\mathrm{NaOH})$ & & $83.0 \pm 1.8$ \\
$\mathrm{CE}$ & $50 \mu \mathrm{g} / \mathrm{mL}$ & $78.2 \pm 3.9$ \\
& $100 \mu \mathrm{g} / \mathrm{mL}$ & $60.0 \pm 3.0^{*}$ \\
& $200 \mu \mathrm{g} / \mathrm{mL}$ & $20.4 \pm 1.8^{* *}$ \\
& & \\
Catechin & $50 \mu \mathrm{g} / \mathrm{mL}$ & $68.2 \pm 3.8$ \\
& $100 \mu \mathrm{g} / \mathrm{mL}$ & $50.0 \pm 5.0^{*}$ \\
& $200 \mu \mathrm{g} / \mathrm{mL}$ & $32.4 \pm 4.0^{* *}$ \\
Gallocatechin & $50 \mu \mathrm{g} / \mathrm{mL}$ & $68.0 \pm 7.0$ \\
& $100 \mu \mathrm{g} / \mathrm{mL}$ & $39.7 \pm 7.0^{* *}$ \\
& $200 \mu \mathrm{g} / \mathrm{mL}$ & $29.0 \pm 6.0^{* *}$ \\
\hline
\end{tabular}

Statistical: Tukey Kramer test $n=15, p<0.05^{*} ; \mathrm{p}<0.001^{* *}$ Platelets were pre-incubated with each compound for $5 \mathrm{~min}$. at $37^{\circ} \mathrm{C}$ before stimulation. Each value represents the mean \pm SD of 15 independent experiments.

In the current study, we have found that the inhibitory effect were, in all cases, dose dependent at concentrations between $50-200 \mu \mathrm{g} / \mathrm{mL}$. Platelet aggregation is known to be a result of complex signal transduction cascade reactions brought about by stimulants. Blood platelets contain three types of secretory organelles: lysosomes, $\alpha$-granules and dense granules. In these secretory organelles, there are different biologically relevant molecules that are released in response to 
TABLE II - Effects of Croton celtidifolius Baill, crude extract (CE), catechin and gallocatechin on platelet aggregation induced by $6 \mu \mathrm{M}$ of ADP.

\begin{tabular}{lcl}
\hline Treatment & & ADP $(\%)$ \\
\hline Control (1mM-NaOH) & & $71.0 \pm 3.4$ \\
CE & $50 \mu \mathrm{g} / \mathrm{mL}$ & $68.3 \pm 4.8$ \\
& $100 \mu \mathrm{g} / \mathrm{mL}$ & $53,8 \pm 2.7^{*}$ \\
& $200 \mu \mathrm{g} / \mathrm{mL}$ & $17.6 \pm 2.3^{* *}$ \\
& & \\
Catechin & $50 \mu \mathrm{g} / \mathrm{mL}$ & $70.0 \pm 3.0$ \\
& $100 \mu \mathrm{g} / \mathrm{mL}$ & $60.4 \pm 2.0^{*}$ \\
& $200 \mu \mathrm{g} / \mathrm{mL}$ & $40.0 \pm 1.4^{* *}$ \\
Gallocatechin & & \\
& $50 \mu \mathrm{g} / \mathrm{mL}$ & $61.0 \pm 3.1^{*}$ \\
& $100 \mu \mathrm{g} / \mathrm{mL}$ & $24.0 \pm 3.3^{* *}$ \\
& $200 \mu \mathrm{g} / \mathrm{mL}$ & $15.5 \pm 1.4^{* *}$ \\
\hline
\end{tabular}

Statistical: Tukey Kramer test $n=15, p<0.05^{*} ; \mathrm{p}<0.001^{* *}$ Platelets were pre-incubated with each compound for $5 \mathrm{~min}$ at $37^{\circ} \mathrm{C}$ before stimulation. Each value represents the mean $\pm \mathrm{SD}$ of 15 independent experiments.

platelet agonists, like thrombin or collagen. The platelet secretory process plays a key role in thrombosis. Moreover, platelets play a very important role in the pathogenesis of cardiovascular diseases and at the site of injury or in atherosclerosis vessel wall stability of atherosclerotic plaques (Varughese, Lip, 2005; Vorchheimer, Becker, 2006). Using ATP production as an index of platelet secretion capacity, we observed a decreased platelet ATP production. A significant effect was observed after cells were incubated with the flavonoids at a concentration of $200 \mu \mathrm{g} / \mathrm{mL}$ (Table III). The second platelet aggregation phase, which is dependent on platelet secretion, let us to conclude that the reaction release inhibition could be, in this study, the mechanism involved in the antiaggregatory effects of these compounds. Our results are in agreement with many studies that have shown that flavonoids significantly inhibited platelet adhesion, aggregation and secretion (Polette et al., 1996; Mardla, Kobzar, Samel, 2004; Guglielmone et al., 2005; Vitseva et al., 2005). Polette et al. (1996) reported that catechins inhibited N-3 fatty acid-induced aggregation in washed platelets. Furthermore, the most frequently studied flavonoid, quercetin, has been shown to have biological properties consistent with a sparing effect on the cardiovascular system. Quercetin and other flavonoids modify eicosanoid biosynthesis, prevent platelet aggregation and promote relaxation of cardiovascular smooth muscle (Cody, 1988; Mardla, Kobzar, Samel, 2004). The results obtained in the present study demonstrate that both, catechin and gallocatechin, were effective in preventing platelet aggregation in the presence of two agonists.
TABLE III - Effects of Croton celtidifolius Baill, crude extract (CE), catechin and gallocatechin on platelet secretion stimulated by $4 \mu \mathrm{g} / \mathrm{mL}$ collagen.

\begin{tabular}{lcc}
\hline Treatment & & Secretion (\%) \\
\hline Control (1mM-NaOH) & & $100 \pm 0.0$ \\
CE & $50 \mu \mathrm{g} / \mathrm{mL}$ & $73.3 \pm 4.0^{*}$ \\
& $200 \mu \mathrm{g} / \mathrm{mL}$ & $43.3 \pm 4.1^{* *}$ \\
Catechin & & \\
& $50 \mu \mathrm{g} / \mathrm{mL}$ & $83.0 \pm 2.6^{*}$ \\
Gallocatechin & $200 \mu \mathrm{g} / \mathrm{mL}$ & $42.0 \pm 2.0^{* *}$ \\
& $50 \mu \mathrm{g} / \mathrm{mL}$ & $72.0 \pm 1.5^{*}$ \\
& $200 \mu \mathrm{g} / \mathrm{mL}$ & $36.3 \pm 6.6^{* *}$ \\
\hline
\end{tabular}

Statistical: Tukey Kramer test $\mathrm{n}=5, \mathrm{p}<0.05^{*} ; \mathrm{p}<0.001^{* *}$ Platelets were pre-incubated with each compound for $5 \mathrm{~min}$ at $37^{\circ} \mathrm{C}$ before stimulation. Each value represents the mean \pm SD of 5 independent experiments.

Finally, to evaluate the effects of flavonoids on the enzymes of blood coagulation, screening tests were carried out in relation to activated PT, activated partial APTT and TT. High concentration of flavonoids $(200 \mu \mathrm{g} / \mathrm{mL})$ did not increase the clotting time of the three parameters evaluated under the experimental conditions (Table IV). It is worth noting that the pre-incubation of plasma at a maximum

TABLE IV - Effects of Croton celtidifolius Baill, crude extract (CE), catechin and gallocatechin $(200 \mu \mathrm{g} / \mathrm{mL})$ on prothrombin time (PT), partial thromboplastin time (APTT) and thrombin time (TT). The plasma was incubated with each compound for $5 \mathrm{~min}$. at $37^{\circ} \mathrm{C}$. Each value represents the mean $\pm \mathrm{SD}$ of 6 independent experiments.

\begin{tabular}{ll}
\hline Test/ Treatment & Time $(\mathrm{s})$ \\
\hline PT/ & \\
Control & $12.4 \pm 0.5$ \\
CE & $11.8 \pm 0.5$ \\
Catechin & $11.4 \pm 0.6$ \\
Gallocatechin & $12.1 \pm 0.3$ \\
APTT/ & \\
Control & $40.0 \pm 1.8$ \\
CE & $40.3 \pm 2.0$ \\
Catechin & $41.2 \pm 1.0$ \\
Gallocatechin & $41.6 \pm 1.4$ \\
TT/ & \\
Control & $15.5 \pm 0.3$ \\
CE & $14.4 \pm 0.2$ \\
Catechin & $14.0 \pm 0.2$ \\
Gallocatechin & $14.8 \pm 0.3$ \\
\hline Statistical: Tukey Kramert test & \\
\hline
\end{tabular}

Statistical: Tukey Kramer test $n=6 p>0.05$ 
dosage $(200 \mu \mathrm{g} / \mathrm{mL})$ did not promote inhibitory action on fibrinogen as observed on TT. In addition, neither had an inhibitory effect upon the activity of the other plasma proteins as measured by PT and APTT.

\section{CONCLUSION}

The obtained data demonstrate that the activity of $C$. celtidifolius crude hidroalcoolic extract and its isolated compounds, catechin and gallocatechin, are limited to primary haemostasis in human blood. However, future studies are necessary to elucidate the biochemical platelet al.terations which are associated with the effects of these compounds to promote inhibition of platelet secretion and aggregation

\section{ACKNOWLEDGMENTS}

This work was funded by grants from Conselho Nacional de Desenvolvimento Científico e Tecnológico (CNPq) and from Fundação de Amparo a Pesquisa do Estado de São Paulo (FAPESP).

\section{RESUMO}

\section{Atividade antiplaquetária do Croton celtidifolius}

Croton celtidifolius Baill é uma árvore encontrada na Mata Atlântica, no sul do Brasil, principalmente no estado de Santa Catarina. A infusão da casca e folhas dessa planta medicinal é utilizada na medicina popular para o tratamento de doenças inflamatórias. A atividade antiagregante do extrato bruto de C. celtidifolius (CE) e de seus flavonóides isolados por coluna cromatográfica $(C C)$, catequina e galocatequina, foi avaliada em plaquetas humanas. O plasma rico em plaquetas (PRP) foi incubado com diferentes concentrações dos flavonóides testados $(50$ - $200 \mu \mathrm{g} / \mathrm{mL})$ e posteriormente a agregação foi induzida pelos agonistas adenosina 5 'difosfato (ADP) e colágeno. Na concentração de $200 \mu \mathrm{g} / \mathrm{mL}$ o CE, a catequina e a galocatequina inibiram a agregação plaquetária induzida pelos agonistas. A produção de ATP foi utilizada como um índice de capacidade de secreção plaquetária e observamos uma diminuição na produção de ATP nas plaquetas tratadas com os flavonóides e estimuladas com o colágeno. Por outro lado, os flavonóides não promoveram um efeito inibitório no tempo de protrombina $(P T)$, tempo de tromboplastina parcial ativada (APTT) e tempo de trombina (TT). Essas observações sugerem que o C. celtidifolius exerce, in vitro, uma ação inibitória nas plaquetas através da inibição da secreção e agregação plaquetária.
UNITERMOS: Croton celtidifolius. Agregação plaquetária. Catequinas. Galocatequinas. Coagulação.

\section{REFERENCES}

ANDRIOLI, G.; ORTOLANI, R.; FONTANA, L.; GAINO, S.; BELLAVITE, P.; LECHI, C.; MINUZ, P.; MANZATO, F.; TRIDENTE, G.; LECHI, A. Study of platelet adhesion in patients with uncomplicated hypertension. J. Hypertens., v.14, n.10, p.1215-1221, 1996.

BLUESTEIN, D. Research approaches for studying flowinduced thromboembolic complications in blood recirculating devices. Expert Rev. Med. Devices, v.1, n.1, p.65-80, 2004.

BORN, G. V.; CROSS, M. J. The aggregation of blood platelets. J. Physiol., v.168, p.178-195, 1963.

BRUSCHI, G.; BRUSCHI, M. E.; CAROPPO, M.; ORLANDINI, G.; SPAGGIARI, M.; CAVATORTA, A. Cytoplasmic free $[\mathrm{Ca} 2+]$ is increased in the platelets of spontaneously hypertensive rats and essential hypertensive patients. Clin. Sci., v.68, n.2, p.179-184, 1985.

CHEN, Z. P.; CAI, Y.; PHILLIPSON, J.D. Studies on the antitumour, anti-bacterial, and wound-healing properties of dragon's blood. Planta Med., v.60, n.6, p.541-545, 1994.

CODY, V. Crystal and molecular structures of flavonoids. Prog. Clin. Biol. Res., v.280, p.29-44. 1988.

CONI, E.; DI BENEDETTO, R.; DI PASQUALE, M.; MASELLA, R.; MODESTI, D.; MATTEI, R.; CARLINI, E. A. Protective effect of oleuropein, an olive oil biophenol, on low density lipoprotein oxidizability in rabbits. Lipids, v.35, n.1, p.45-54, 2000.

DUTTA-ROY, A. K.; CROSBIE, L.; GORDON, M. J. Effects of tomato extract on human platelet aggregation in vitro. Platelets, v.12, n.4, p.218-227, 2001.

ERNE, P.; BOLLI, P.; BURGISSER, E.; BUHLER, F. R. Correlation of platelet calcium with blood pressure. Effect of antihypertensive therapy. New Engl. J. Med., v.310, n.17, p.1084-1088, 1984.

GÖRLACH，A.; BELAIBA， R. S.; HESS，J.; KIETZMANN, T. Thrombin activates the $\mathrm{p} 21$-activated kinase in pulmonary artery smooth muscle cells. Role in tissue factor expression. Thromb. Haemost., v.93, n.6, p.1168-1175, 2005. 
GUGLIELMONE, H. A.; AGNESE, A. M.; NUNEZ MONTOYA, S. C.; CABRERA, J. L. Inhibitory effects of sulphated flavonoids isolated from Flaveria bidentis on platelet aggregation. Thromb. Res., v.115, n.6, p.495-502, 2005.

HERNÁNDEZ HERNÁNDEZ, R.; ARMAS de HERNÁNDEZ, M. J.; ARMAS PADILLA, M. C.; CARVAJAL, A. R.; GUERRERO PAJUELO, J. Platelet actions of calcium channel blockers in hypertension. Clin. Cardiol., v. 20, suppl. 3, p.III25-III30, 1997.

MAEDA, N. Y.; BYDLOWSKI, S. P.; LOPES, A. A. Increased tyrosine phosphorylation of platelet proteins including pp125 (FAK) suggests endogenous activation and aggregation in pulmonary hypertension. Clin. Appl. Thromb. Hemost., v.11, n.4, p.411-415, 2005.

MARDLA, V.; KOBZAR, G.; SAMEL, N. Potentiation of antiaggregating effect of prostaglandins by alphatocopherol and quercetin. Platelets, v.15, n.5, p.319-324, 2004.

MASSBERG, S.; SCHURZINGER, K.; LORENZ, M.; KONRAD, I.; SCHULZ, C.; PLESNILA, N.; KENNERKNECHT, E.; RUDELIUS, M.; SAUER, S.; BRAUN, S.; KREMMER, E.; EMAMBOKUS, N. R.; FRAMPTON, J.; GAWAZ, M. Platelet adhesion via glycoprotein IIb integrin is critical for atheroprogression and focal cerebral ischemia: an in vivo study in mice lacking glycoprotein Ilb. Circulation, v.112, n.8, p.11801188, 2005.

NARDI, G. M.; FELIPPI, R.; DALBO, S.; SIQUEIRAJUNIOR, J. M.; ARRUDA, D. C.; DELLE MONACHE, F.; TIMBOLA, A. K.; PIZZOLATTI, M. G.; CKLESS, K.; RIBEIRO-DO-VALLE, R. M. Anti-inflammatory and antioxidant effects of Croton celtidifolius bark. Phytomedicine, v.10, n.2/3, p.176-184, 2003.

OLAS, B.; WACHOWICZ, B.; STOCHMAL, A.; OLESZEK, W. Inhibition of blood platelet adhesion and secretion by different phenolics from Yucca schidigera Roezl. bark. Nutrition, v.21, n.2, p.199-206, 2005.
PASCUAL, C.; ROMAY, C. Effect of antioxidants on chemiluminescence produced by reactive oxygen species. J. Biolumin. Chemilumin., v.7, n.2, p.123-132, 1992.

POLETTE, A.; LEMAITRE, D.; LAGARDE, M.; VERICEL, E. N-3 fatty acid-induced lipid peroxidation in human platelets is prevented by catechins. Thromb. Haemost., v.75, n.6, p.945-949, 1996.

RAHMAN, K.; BILLINGTON, D. Dietary supplementation with aged garlic extract inhibits ADP-induced platelet aggregation in humans. J. Nutr., v.130, n.11, p.2662$2665,2000$.

RECHNER, A. R.; KRONER, C. Anthocyanins and colonic metabolites of dietary polyphenols inhibit platelet function. Thromb. Res., v.116, n.4, p.327-334, 2005.

TRIPLETT, D. A.; HARMS, C. S.; KOEPKE, J. A. The effect of heparin on the activated partial thromboplastin time. Am. J. Clin. Pathol., v.70, suppl.3, p.556-559, 1978.

VAISBERG, A. J.; MILLA, M.; PLANAS, M. C.; CORDOVA, J. L.; DEAGUSTI, E. R.; FERREYRA, R.; MUSTIGA, M. C.; CARLIN, L.; HAMMOND, G. B. Taspine is the cicatrizant principle in Sangre de Grado extracted from Croton lechleri. Planta Med., v.55, n.2, p.140-143, 1989.

VARUGHESE, G. I.; LIP, G. Y. Is hypertension a prothrombotic state? Curr. Hypertens. Rep., v.7, n.3, p.168-173, 2005.

VITSEVA, O.; VARGHESE, S.; CHAKRABARTI, S.; FOLTS, J. D.; FREEDMAN, J. E. Grape seed and skin extracts inhibit platelet function and release of reactive oxygen intermediates. J. Cardiovasc. Pharmacol., v.46, n.4, p.445-451, 2005.

VORCHHEIMER, D. A.; BECKER, R. Platelets in atherothrombosis. Mayo Clin. Proc., v.81, n.1, p.59-68, 2006.

Recebido para publicação em 28 de maio de 2007 Aceito para publicação em 30 de novembro de 2007 